\title{
Expressed genes in the lymphoid organ of broodstock banana prawn (Penaeus merguiensis) using suppression subtractive hybridization
}

\begin{abstract}
Most systemic viral infections in penaeid prawns are associated with the formation of lymphoid organ spheroid (LOS) cells in the lymphoid organ (LO). The development of spheroids is suggested to be a major defence mechanism against viral infection in penaeids. Spheroids were observed in a broodstock population of banana prawns (Penaeus merguiensis), while these changes were not identified in the wild population. This opportunity was taken to see how well suppression subtractive hybridization ( $\mathrm{SSH}$ ) would resolve a histological change with no known aetiology. A total of 316 sequenced clones were clustered into 141 contigs and $51.6 \%$ of the clones shared significant similarities to known peptide or nucleotide sequences in the NCBI GenBank database. These transcripts were assigned into 8 categories, including immune related genes $(2.5 \%)$, synthesis, processing and regulation-related proteins $(4.4 \%)$, ribosomal proteins $(6.3 \%)$, proteases and inhibitors $(7.0 \%)$, energy and metabolism factors $(7.3 \%)$, structural and cytoskeletal related proteins $(10.1 \%)$ and other sequences $(13.9 \%)$. Many sequenced clones $(48.4 \%)$ from the libraries had no significant similarity to amino acids/nucleotides in the public database revealing the ability of this method in disclosing new differentially expressed genes in the lymphoid organ of prawns. Despite the detection of differential gene expression in the SHH libraries, unfortunately there were no viral genomes identified which were associated with spheroid formation within the $\mathrm{LO}$ of penaeids. However, polymerase chain reaction (PCR) amplification with HPV140F and HPV140R primers suggested that the development of spheroid cells in the lymphoid organ of the broodstock population most likely due to Penaeus merguiensis hepandensovirus (PmeDV) which maybe the senior synonym of lymphoidal parvovirus (LPV).
\end{abstract}

Keywords: Banana Prawn, Penaeus merguiensis hepandensovirus, Lymphoid Organ, Spheroid Cells, Suppression Subtractive Hybridisation, Expressed Genes
Volume 2 Issue I - 2015

\author{
Rusaini ${ }^{1,2}$ Leigh Owens ${ }^{2}$ \\ 'Department of Animal Husbandry and Fishery, Tadulako \\ University, Indonesia \\ IIO-BAS Bulgarian Academy of Sciences, Bulgaria \\ ${ }^{2}$ College of Public Health, Medical and Veterinary Sciences, James \\ Cook University, Australia \\ ${ }^{3}$ LAMANS Management Services S.A, Greece
}

Correspondence: Leigh Owens, College of Public Health, Medical and Veterinary Sciences, James Cook University, Townsville, Queensland 48I I,Australia, Tel 6 I 7 478I 4632, Email leigh.owens@jcu.edu.au

Received: December 15, 2014 | Published: March 14, 2015
Abbreviations: LOS, Lymphoid Organ Spheroid; LO, Lymphoid Organ; SSH, Suppression Subtractive Hybridization; NCBI, National Centre For Biotechnology Information; PCR, Polymerase Chain Reaction; RT-PCR, Reverse Transcript-PCR; HPV, Hepatopancreatic Parvovirus; Pmedv, Penaeus Merguiensis Hapandensovirus; LPV, Lymphoidal Parvovirus; H \& E, Haematoxylin and Eosin; RNA, Ribonucleic Acid; DNA, Deoxyribonucleic Acid; cDNA, Complementary DNA; BLAST, Basic Local Alignment Search Tool

\section{Introduction}

The rapid development of the cultured prawn industry is associated with environmental and sociological disturbances in land use, the ecology of the aquatic organisms and global trade patterns. A major consequence of these changes is the emergence and the spread of infectious diseases. In the late 1980s, previously unknown diseases emerged in the cultured prawns both in Asia and Americas, spread rapidly to all countries farming prawns and brought catastrophe to this industry around the world. Even though some progress has been made to deal with these challenges and recovery has taken place in recent years, infectious diseases, in particular viral diseases still remain a major problem to the prawn aquaculture industry. ${ }^{1,2}$

Several viruses have been reported to cause diseases in the wild and cultured banana prawn Penaeus merguiensis including hepatopancreatic parvo-like virus (HPV) ${ }^{3,4,5,6}$ the Australian strain of HPV (Penaeus merguiensis hepandensovirus, PmeDV) .7,8 lymphoidalparvo like-virus (LPV). ${ }^{9}$ white spot syndrome virus (WSSV). ${ }^{10}$ and spawner-isolated mortality virus (SMV). ${ }^{11}$ Moreover, even though there is no report on banana prawns naturally infected with gill-associated virus (GAV), experimental infection suggested that this species may be susceptible to GAV ${ }^{12}$

Histopathologically, most of these systemic viruses cause spheroid development within the lymphoid organ (LO) of banana prawns. The formation of spheroid cells in the lymphoid organ is a major defence mechanism to viral infection in penaeid prawns.$^{13,14}$ Currently, in northern Queensland approximately $75-100 \%$ of cultured banana prawns from different family lines have lymphoid organ spheroid (LOS) cells that occupied more than $40 \%$ of the lymphoid organ area (Owens, unpublished data). However, no candidate virus has been identified in causing these spheroid formations.

Several studies have been conducted into disclosing differential gene transcripts of banana prawns. Most of published work on gene transcripts of $P$. merguiensis pays particular attention to the haemocytes. ${ }^{15,16,17}$ and ovaries. ${ }^{8,19,20,21}$ Only a few studies on the tissue distribution of the genes including muscle, gonad, gills, brain, heart, intestine, hepatopancreas and lymphoid organ have been carried out. ${ }^{15,20}$ Furthermore, application of suppression subtractive hybridization ( $\mathrm{SSH})$ in banana prawns has only been performed to identify genes related to the ovarian development.$^{18,20,21}$ Therefore, 
this study was conducted to determine the expressed genes in the lymphoid organ and detect the viral aetiology of spheroid cells in $P$. merguiensis using suppression subtractive hybridization (SSH).

\section{Materials and methods}

\section{Experimental Animals}

Wild banana prawns Penaeusmerguiensis that did nothave spheroids in the lymphoid organ were caught with a cast net in creeks around Townsville, Queensland, Australia. Broodstock P. merguiensis that did have spheroids in the lymphoid organ were sourced from a hatchery in northern Queensland where the lymphoid organs were extracted in situ. Prior to histological examination and LO extraction, prawns were anesthetised by placing them in iced water for few minutes.

\section{Histology}

Experimental prawns were fixed in Davidson's fixative for 48 hours. The cephalothorax was cut mid sagitally, placed in a histocassette and preserved in $70 \%$ ethanol and then processed for routine histological examination using standard paraffin embedded protocol. ${ }^{22}$ Paraffin blocks were cut at $5 \mu \mathrm{m}$ and stained with haematoxylin and eosin $(\mathrm{H}$ $\&$ E) and examined under a light microscopy.

\section{Suppression Subtractive Hybridization}

Twenty Broodstock $P$. merguiensis with an average body weight of $38.8 \pm 6.8 \mathrm{~g}$ (SD) from a broodstock population and 20 banana prawns with a mean body weight of $12.0 \pm 5.2 \mathrm{~g}$ from the wild caught population were used for the suppression subtractive hybridization. Total RNA was separately extracted from the lymphoid organ of wild and hatchery populations using SV Total RNA Isolation System (Promega) following the protocol of the manufacturer. Polyadenylated $($ poly $(\mathrm{A})+)$ RNA was isolated from pooled total RNA using PolyATract $\AA$ mRNA Isolation System III (Promega) as described by the company. Prior to use, $1000 \mu \mathrm{l}$ poly(A) RNA was concentrated by freeze drying (Telstar 23750 - Cryodos -50/230 V $50 \mathrm{~Hz}$, the UK), re-dissolved in $25 \mu$ RNAase-free water and kept at $-80^{\circ} \mathrm{C}$ until used. The concentration and purity of nucleic acids were determined using spectrophotometry (NanoPhotometerTM, Implen, Germany).

Suppression subtractive hybridization was performed using the PCR-Select cDNA Subtraction Kit (Clontech, USA) following the manufacturer's instructions to generate cDNA forward libraries between Broodstock prawns (tester) and wild caught prawns (driver). The tester cDNA was prepared from $1.19 \mu \mathrm{g}$ of poly (A)+ RNA and the driver cDNA was synthesised from $0.02 \mu \mathrm{g}$ of poly (A)+ RNA. Tester and driver cDNAs were digested with Rsa I to obtain shorter blunt-ended molecules. Rsa I-digested tester cDNA was divided into two portions. One portion was ligated with adaptor 1 and another one with adaptor 2R. In the first step of hybridization, an excess of driver cDNA was mixed with each tester cDNA, heat denatured and allowed to anneal to generate several fractions of molecules. In the second hybridization step, the two tester cDNAs from the first step were mixed together in the presence of freshly denatured driver cDNA to further enrich the differentially expressed genes. Finally, two rounds of PCR were performed to exponentially amplify the differential gene expression and suppress the common genes of the two cDNA samples. The subtracted PCR products were then inserted into pGEM-T easy vectors (Promega) and transformed into JM109 competent Escherichia coli cells which were plated onto agar containing ampicillin, X-gal (5-bromo-4-chloro-3-indolyl- $\beta$-Dgalactopyranoside) and IPTG (isopropyl- $\beta$-D-thiogalactopyranoside). Plasmid DNA was isolated from randomly selected white colonies and commercially sequenced by Macrogen Inc., Korea. Nucleotide sequences were analysed with BLASTx and BLASTn against known amino acid/nucleotide sequences on public databases (NCBI). Sequences with E-values $<1$ e- 05 were considered significant.

Reverse Transcriptase - Polymerase Chain Reaction (RT-PCR) Amplification with Bunyavirus Primers and PCR Amplification with Parvovirus Primers

To investigate the possibility of the aetiological agent of spheroid cells in P. mergueinsis was caused by virus with no poly (A) tail, several primers sourced from related-genus Phlebo virus within Bunyaviridae family including Mourilyan virus (AY927991), Uukuniemi virus (M17417) and Toscana virus (EU003175) were designed to amplify possible viral genomes in the Broodstock population. Total RNA was extracted from the lymphoid organ of Broodstock P. merguiensis (20 prawns) using SV Total RNA Isolation System (Promega). Complementary DNA (cDNA) was synthesised from total RNA using random hexamer primers (SuperScriptTM III first-strand synthesis system for RT-PCR, Invitrogen, USA). The RTnested PCR was performed using primers MoV24F and MoV25R in the primary PCR, and primers MoV148F and MoV149R in the nested PCR (Table 1).

Table I Primer sequences used to amplify presumptive Bunyavirus and Parvovirus in the lymphoid organ of a Broodstock population of Penaeus merguiensis

\begin{tabular}{|c|c|c|c|c|}
\hline Primer name & Sequences (5' to 3 ') & \multicolumn{2}{|c|}{ Expected amplicon (bp) GeneBank ID } & References \\
\hline \multicolumn{5}{|c|}{ Bunyavirus Primers } \\
\hline MoV24F & GGG ATG GTG TTG CCA TAC AAA GG & 610 & AY92799I & Cowley et al. ${ }^{23}$ \\
\hline MoV25R & GTC ATT AGC TGG TCT TAG TTT TCA C & & & \\
\hline MoVI48F & ACA GTT TGT CAA GCT CAC AGG ATG & 322 & AY92799I & Cowley et al. ${ }^{23}$ \\
\hline MoVI49R & AGA AGC GCC ATT CTG ATG AAC ATC & & & \\
\hline MoV2IOF & GGC CAC CCT TAC TAT CCT TG & 249 & AY92799I & Present study \\
\hline MoV439R & ATT GTC CTT GTCTCG GGG TC & & & \\
\hline UUKV2558F & TTC CAA TAA GTG TAG CCC AAG & 668 & MI74I7 & Present study \\
\hline UUKV3205R & AAA GAC ACG GCT ACA TGG AAC & & & \\
\hline TosV2667F & AGC GAA AAG CAA TTT ATC TCA & 416 & EU003I75 & Present study \\
\hline TosV3064R & CTC ATA GCC ATC AGA ACC A & & & \\
\hline \multicolumn{5}{|c|}{ Parvovirus Primers } \\
\hline HPVI40F & CTA CTC CAA TGG AAA CTT CTG AGC & 140 & DQ45878I & La Fauce et al. ${ }^{7}$ \\
\hline HPVI40R & GTG GCG TTG GAA GGC ACT TC & & & \\
\hline
\end{tabular}


In the primary amplification, PCR mixture contained $12.5 \mu \mathrm{l}$ of GoTaq ${ }^{\circledR}$ Green Master Mix (Promega, USA), $1 \mu$ of DNA template, and $0.75 \mu \mathrm{l}(10 \mu \mathrm{M})$ of each primer. This PCR reaction volume was adjusted with nuclease free water (Promega) to a final volume of $25 \mu$ l. The PCR amplification was performed in a Master cycler gradient 5333 (Eppendorf, Germany) with an initial denaturation $95^{\circ} \mathrm{C}$ for 2 mins, 35 cycles for 30 s denaturation at $95^{\circ} \mathrm{C}, 30 \mathrm{~s}$ annealing at $60^{\circ} \mathrm{C}, 40 \mathrm{~s}$ extension at $72^{\circ} \mathrm{C}$, and then followed by final extension for 7 mins at $72^{\circ} \mathrm{C}$. In the nested PCR amplification, $2 \mu \mathrm{l}$ of primary PCR products was amplified using primers MoV148F and MoV149R in $25 \mu \mathrm{l}$ reaction mixture. Amplification profile was different from the primary PCR with annealing temperature at $58^{\circ} \mathrm{C}$ and a shorter extension time for $30 \mathrm{~s} .{ }^{23}$ For other primers including primers TosV2667F/TosV3064R, the reaction mixture was the same as described for the primary PCR of primers MoV24F/MoV25R but it was slightly different in amplification profile. Amplification profile of primers MoV210F/MoV439R and primers UUKV2558F/ UUKV3205R consisted of initial denaturation at $94^{\circ} \mathrm{C}$ for $7 \mathrm{mins}, 40$ cycles for $45 \mathrm{~s}$ denaturation at $94^{\circ} \mathrm{C}, 45 \mathrm{~s}$ annealing at $58^{\circ} \mathrm{C}, 1 \mathrm{~min}$ extension at $72^{\circ} \mathrm{C}$, and then followed by final extension for 5 mins at $72^{\circ} \mathrm{C}$.

Deoxyribonucleic acid (DNA) was isolated from the LO of Broodstock banana prawns (20) using a High Pure PCR Template Preparation Kit (Roche Diagnostics), while DNA from the LO of wild population (20 banana prawns) was extracted using Wizard $\AA$ SV Genomic DNA Purification System (Promega). Using HPV140F/ HPV140R primers, the PCR product was amplified at $94^{\circ} \mathrm{C}$ for 7 mins for initial denaturation, 40 cycles for denaturation at $94^{\circ} \mathrm{C}$ for $45 \mathrm{~s}$, annealing at $65^{\circ} \mathrm{C}$ for $45 \mathrm{~s}$, extension at $72^{\circ} \mathrm{C}$ for $1 \mathrm{~min}$, and then finally subjected to extension at $72^{\circ} \mathrm{C}$ for 5 mins.$^{7}$ Amplified products $(10$ $\mu 1)$ were visualised on a $1.2 \%$ agarose-TAE gels containing GelRed $(10,000 \times$ in water) at a concentration of $0.5: 10,000$. Gels were visualised and photographed using InGenius LHR, gel documentation and analysis system (Syngene, UK).

\section{Results}

\section{Histology}

Routine histological examination with $\mathrm{H}$ \& E stain (Figure 1) showed that 12 out of 12 of Broodstock P. Merguiensis had lymphoid organ spheroid cells, while these pathological changes were not observed in the lymphoid organ of wild caught prawns (12/12). These abnormal cells had more basophilic cytoplasm and had no central lumen compared to the normal stromal matrix cells of the lymphoid organ. Some spheroids were bounded by elongated flattened cells or fibrous connective tissue and had cytoplasmic vacuoles.

\section{Suppression Subtractive Hybridization}

Two bands with approximate $250 \mathrm{bp}$ and $200 \mathrm{bp}$ were visualised following gel electrophoresis and these PCR product was used as SSH libraries. Following hand picking of selected white colonies, 328 clones were sequenced and a total of 316 sequences were clustered into 141 contigs (consensus sequences) with a range of fragment sizes between $47 \mathrm{bp}$ and $427 \mathrm{bp}$. Homology search revealed that around $51.6 \%$ of the total clones (163 out of 316 clones) shared significant similarities to known amino acids or nucleotides in the NCBI GenBank database. Transcripts were assigned functions as predicted from sequence homology from the public database and grouped into 8 categories (Figure 2). Many sequenced clones (48.4\%) from the SSH libraries had no significant similarity to amino acids/nucleotides in the public database. This indicates the ability of SSH method in revealing new differentially expressed genes in the lymphoid organ of penaeid species.

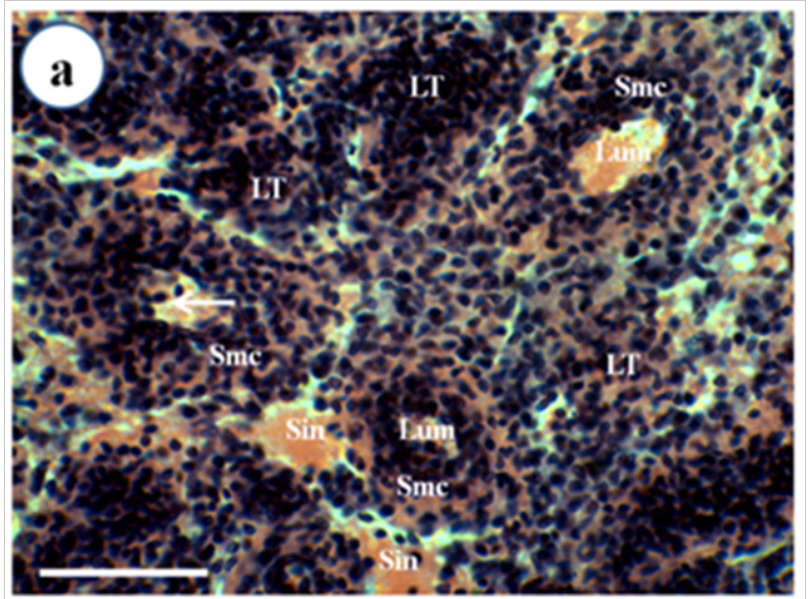

Figure I (a) Normal lymphoid tubule (LT) without lymphoid organ spheroid (LOS) cells of wild caught P. merguiensis. Lymphoid tubules consist of lumen (Lum) surrounded by stromal matrix cells (Smc). Haemocytes (arrow) sometimes can be observed within the tubular lumen.

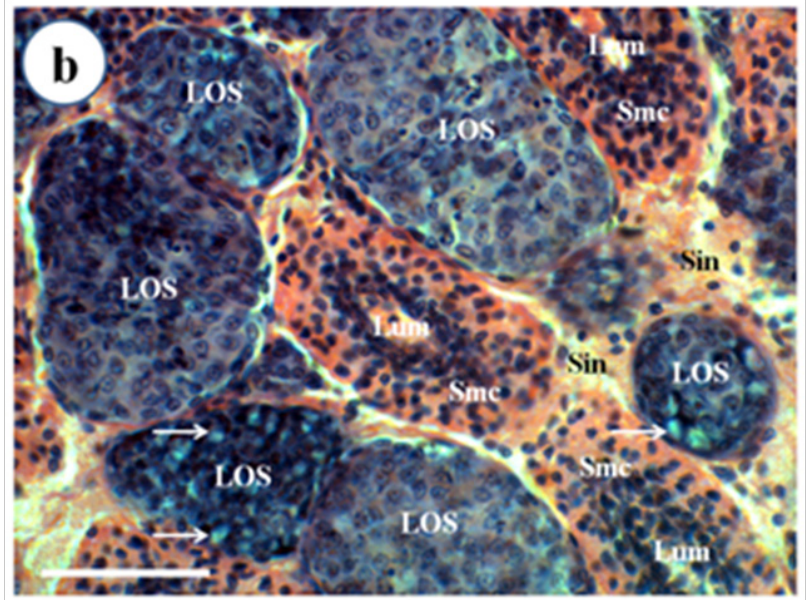

Figure I (b) Spheroid development within the LO of broodstock P. mergueinsis. Spheroid cells are formed in the haemal sinuses (Sin) and appear to have a more basophilic cytoplasm and lack of a central lumen compared to the normal lymphoid tubule. Some spheroids demonstrated cytoplasmic vacuoles (arrow). H \& E stain. Scale bar: $50 \mu \mathrm{m}$.

Figure I Light micrograph of longitudinal section of the LO of Penaeus merguiensis.

Reverse Transcriptase - Polymerase Chain Reaction (RT-PCR) Amplification with Bunyavirus Primers and PCR Amplification with Parvovirus Primers

Primary PCR with $\mathrm{MoV} 24 \mathrm{~F} / \mathrm{MoV} 25 \mathrm{R}$ primers produced an approximate $300 \mathrm{bp}$ amplicon from 1 out of 20 samples examined. In the nested PCR, this sample also had an approximate $300 \mathrm{bp}$ amplicon size. However, sequencing results failed to show any similarity to Mourilyan virus or other viral sequences, but similarity with zebra fish DNA (BX248086). Primers MoV210F/MoV439R generated expected amplicons from 2 samples and other different amplicon sizes from several samples. However, once again sequencing results showed no similarity to viral sequences. Primers UUKV2558F/UUKV3205R and TosV2667F/TosV3064R produced no amplicons.

Interestingly, when HPV140F/HPV140R primers were applied, three bands with approximate amplicon sizes of $140 \mathrm{bp}, 200 \mathrm{bp}$ and 
$250 \mathrm{bp}$ appeared in the electrophoretic gel (Figure 3) from DNA templates of the Broodstock population. From the DNA templates of wild caught prawns, only two bands with approximate ampilicons sizes of $200 \mathrm{bp}$ ( 4 samples) and $250 \mathrm{bp}$ ( 5 samples) were observed in the electrophoretic gel. Since the $140 \mathrm{bp}$ was the expected amplicon size for these primers, then three of these four bands (from DNA templates of prawns from the Broodstock population) were extracted from the gel, purified, cloned and sequenced. The sequencing results revealed that the transcripts had $100 \%(5 \mathrm{e}-42)$ nucleotide similarity to Australian Penaeus merguiensis densovirus, PmergDNV (DQ458718) that is currently called Penaeus merguiensis hepandensovirus (PmeDV). ${ }^{24}$

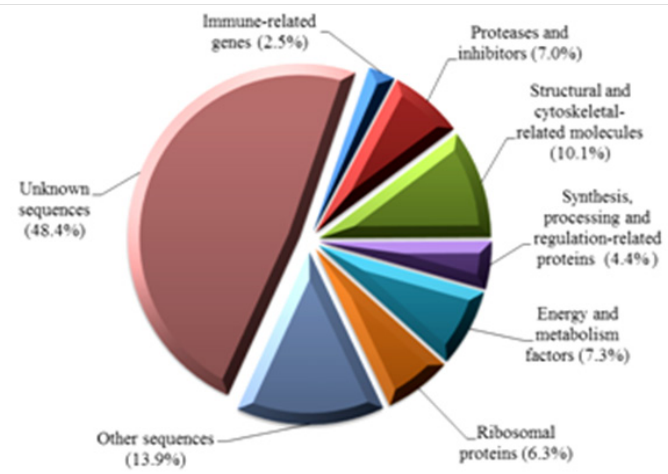

Figure 2 Functional categories of differentially expressed genes from the lymphoid organ cDNA suppression subtractive hybridisation (SSH) libraries of banana prawn, Penaeus merguiensis.

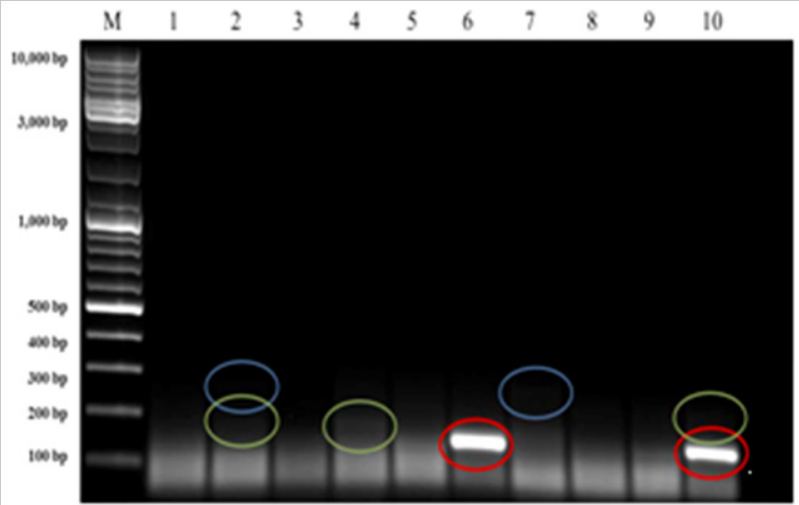

Figure 3a

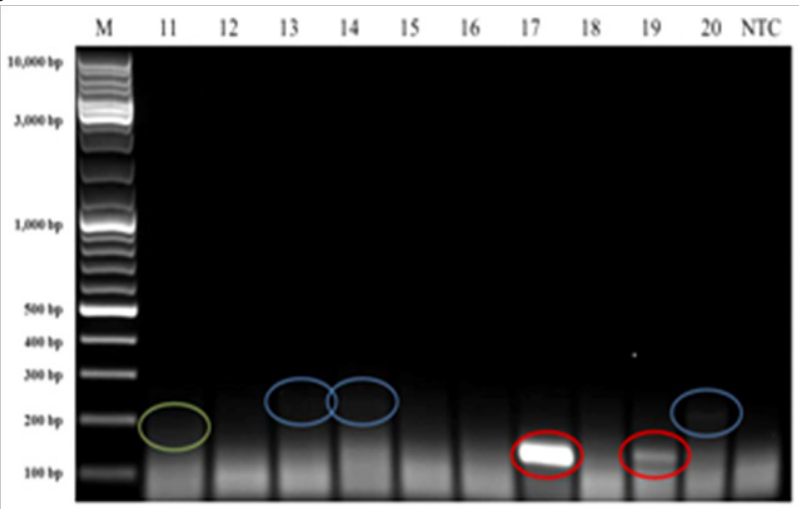

Figure 3b

Figure 3 PCR using HPVI40F and HPVI40R primers produced approximate $140 \mathrm{bp}$ (red highlight), $200 \mathrm{bp}$ (green highlight) and $250 \mathrm{bp}$ (blue highlight) amplicon sizes from broodstock (hatchery maintained) Penaeus merguiensis. Lane $M=10$ kb DNA ladder (GeneRuler ${ }^{T M}$, Fermentas). NTC: Non-Template Control.

\section{Discussion}

\section{Suppression Subtractive Hybridization}

Sequenced clones from the lymphoid organ cDNA SSH libraries were clustered into several functional groups. These genes represented immune-related genes, synthesis, processing and regulation-related proteins, proteases and inhibitors, structural and cytoskeletal related proteins, energy and metabolism factors, and ribosomal proteins, which are all known to be involved in biological process and immune response against infectious pathogens and mostly play an important part in antiviral defence mechanisms (Table 2).

Sequence with homology to viral genes was not identified in the SSH libraries. There are several possible reasons why sequences with homology to viral genes was absent in the SHH libraries. Firstly, the abundance of viral transcripts in the tester cDNAs (Broodstock population) was too low to be expressed using SSH. The abundance of the viral cDNA should be more than 5-fold concentrated in the tester than in the driver or the fractional concentration of mRNA of the viral gene needs to be at least $0.1 \%$ of the total mRNA in order to be detected using this method, because the completion of the second hybridization cannot be achieved if the target cDNA is too low ${ }^{25,26}$. Secondly, the poly (A) tail on the mRNA of the virus may be too short for this SSH technology to be successful. Genes in target should have at least four or more poly(A)s in the tail in order to be amplified with SSH technique, because the complementary DNA synthetic primer of this protocol contains four poly(T)s at the first $5^{\prime}$ end ${ }^{27}$. Finally, the virus causing these cellular changes may not have a poly(A) tail, therefore it could not be expressed in the SSH libraries ${ }^{26}$. It should be noted that $\sim 40 \%$ of the genes of WSSV do not have a poly(A) tail but were expressed ${ }^{28}$. This is why the RT-PCRs for bunyavirus were attempted and further studies are necessary to determine which hypothesis is more likely (see below).

Reverse Transcriptase - Polymerase Chain Reaction (RT-PCR) Amplification with Bunyavirus Primers and PCR Amplification with Parvovirus Primers

The possibility of the viral aetiology of the spheroids in $P$. merguiensis due to virus with no poly(A) tail, was investigated using primers designed from related-genus Phlebo virus of family Bunyaviridae. Bunyaviral genome comprises negative-sense tripartite single-stranded RNA (ssRNA) and the viral mRNAs do not have a poly (A) tail ${ }^{29,30}$. In addition, wild and farmed $P$. monodon and $P$. japonicus were naturally infected with Mourilyan virus (MoV) ${ }^{31}$ and a quite broad host range may have been infected with this virus (Cowley, pers. commun.). However, the lack of positive results showed that these lymphoid organ changes were unlikely to be associated with bunyaviruses.

Hepatopancreatic parvovirus 140 (HPV140) primers were then used to amplify the suspected viral genomes which produced interesting results. This suggested that the formation of spheroid cells in the lymphoid organ of the hatchery prawns was related to PmeDV infection and these cellular changes may be formed as defensive response against this viral infection. The absence of viral (PmeDV) transcripts from cDNA SSH libraries is most likely due to the low viral load in the LO of the tester population. The presence of only four positive samples on the PCR amplification suggested that in chronically infected prawns, either PmeDV was undetected due to low viral load in the remaining samples or this virus has been eliminated during spheroid cell development by an unknown mechanism. ${ }^{32}$ Hasson et al. ${ }^{33}$ who used in situ hybridization in the chronic phase of 
viral infection believed that rapid development of massive spheroid cells within the LO only contained low grade to moderate number of virions in infected foci. According to Tang and Lightner ${ }^{34}$, HPV is an enteric virus targeting hepatopancreatic and intestinal cells of penaeid prawns. Thus, PmeDV could be an enteric virus that spills over into the open circulatory system of all systematic tissues including the LO of the prawns. Indeed, systemic circulating PmeDV has been found in the mud crab, Scylla serrata ${ }^{35}$ In addition, another reported parvovirus of penaeid prawns, lymphoidalparvo-like virus (LPV) that was found in P. merguiensis, P. monodon and P. esculentus also infected systemic tissues including antennal gland, nerve cord and lymphoid organ. Based on the molecular evidence presented here and the principle of Ockham's razor (the law of parsimony), it is highly probable that LPV recorded by Owens et al. ${ }^{9}$ was indeed systemic PmeDV.

Table 2 Genes that may putatively be involved in a range of functional activities identified in cDNA suppression subtractive hybridization (SSH) libraries of the lymphoid organ (LO) of banana prawn, Penaeus merguiensis

\begin{tabular}{|c|c|c|c|}
\hline \multirow{2}{*}{ Genes } & \multicolumn{3}{|l|}{ Putative functional activities } \\
\hline & Viruses & Bacteria & Biological process \\
\hline Heat shock protein (HSP) & $\begin{array}{l}\text { Brenner and Wainberg. }{ }^{54} \text {; de la Vegaet al. }{ }^{6} \text {; } \\
\text { Wanget al. }{ }^{99}\end{array}$ & Rungrassameeet al. ${ }^{93}$ & Ciminoet al. ${ }^{60}$; Jolesch et al. ${ }^{70}$ \\
\hline Anti-lipopolysaccharide factor (ALF) & Liuet al. ${ }^{74} ;$ de la Vegaet al. ${ }^{63} ;$ Antonyet al. ${ }^{51}$ & $\begin{array}{l}\text { de la Vegaet al. }{ }^{64} \text {; } \\
\text { Somboonwiwatet al. }{ }^{95}\end{array}$ & - \\
\hline Cathepsin & - & - & $\begin{array}{l}\text { Mort and Buttle. }{ }^{80} ; \text { Aokiet al. }{ }^{52} ; \text { Wanget al. } \\
{ }^{102} \text {; Stephenset al. }{ }^{96} \text {;Turket al. }{ }^{97}\end{array}$ \\
\hline Metallothionein (MT) & Ilbacket al. ${ }^{69}$ & - & Roesijadi. ${ }^{92}$; Pouranget al. ${ }^{108}$;Amiardet al. ${ }^{50}$ \\
\hline Calreticulin precursor (CRT) & Wanget al. ${ }^{99} ;$ Wanget al. ${ }^{100}$; Liuet al. ${ }^{76}$ & Chenet al[ ${ }^{57}$ & Luanaet al. ${ }^{77} ;$ Qiu and Michalak, ${ }^{89}$ \\
\hline $\begin{array}{l}\text { Eukaryotic translation elongation } \\
\text { factor (eEF) }\end{array}$ & Kawaguchiet al. ${ }^{71}$ & - & Riiset al ${ }^{91}$; Boulbenet al. ${ }^{53} ;$ Wuet al. ${ }^{105}$ \\
\hline $\begin{array}{l}\text { Eukaryotic translation initiation } \\
\text { factor (elF) }\end{array}$ & Wanget al., ${ }^{101}$ & - & Passmoreet al. ${ }^{83}$; Miluzioet al. ${ }^{78}$ \\
\hline Ubiquitin (Ubq) & $\begin{array}{l}\text { Wanget al. }{ }^{103} \text {; Wanget al. }{ }^{99} \text {; Chenet al., }{ }^{56} \text {; } \\
\text { Liuet al., }{ }^{75}\end{array}$ & - & Pickart and Eddins, ${ }^{85}$ \\
\hline Signal peptidase complex (SPC) & Paetzelet al. ${ }^{82}$ & - & Dalbeyet al. ${ }^{62}$; Paetzelet al. ${ }^{82}$ \\
\hline Cytochrome c oxidase (CO) & $\begin{array}{l}\text { Leuet al. }{ }^{74} \text {; Prapavoraratet al.. }{ }^{88} \text {; Liuet al. }{ }^{76} \text {; } \\
\text { Pongsomboonet al. }{ }^{86}\end{array}$ & $\begin{array}{l}\text { Pongsomboonet al. }{ }^{87} \text {; Nayaket } \\
\text { al. }^{81}\end{array}$ & Capaldiet al. ${ }^{55}$ \\
\hline Mitochondrion & $\begin{array}{l}\text { Mohankumar and Ramasamy }{ }^{79} ; \text { Chenet } \\
\text { al. }{ }^{58}\end{array}$ & - & Picardet al. ${ }^{84} ;$ Cloonan and Choi ${ }^{61}$ \\
\hline NADH dehydrogenase & Heet al. ${ }^{67}$; Leuet al. ${ }^{74}$; Prapavoraratet al. ${ }^{88}$ & Heet al. ${ }^{66}$ & Sarkaret al. ${ }^{94}$; Kerscheret al. ${ }^{72}$ \\
\hline Actin & $\begin{array}{l}\text { Chongsatjaet al. }{ }^{59} \text {; Leuet al. }{ }^{74} \text {; Wuet al. }{ }^{106} \text {; } \\
\text { Pongsomboonet al. }{ }^{86}\end{array}$ & Zhanget al. ${ }^{107}$ & Hildet al. ${ }^{68}$ \\
\hline
\end{tabular}

Putative functions against pathogens are assigned based on the up regulation of the genes reported in the published work as indicated. Dash (-) indicates no data available in the published literature.

Furthermore, the formation of spheroids within the lymphoid organ has been detected in many naturally or experimentally infected penaeid species with viral diseases (Rusaini and Owens, 2010). These viruses included LPV . 9 lymphoid organ vacuolization virus (LOVV). ${ }^{36}$, rhabdovirus of penaeid shrimp (RPS).$^{37}$ lymphoid organ virus (LOV)/GAV.$^{38,39}$ and SMV . ${ }^{40}$ The spheroid cell formation has also been implicated to be associated with YHV. ${ }^{41,42}$ TSV ${ }^{43}$, WSSV $44,45,46$ infectious myonecrosis virus (IMNV) ${ }^{47}$ Mourilyan virus (MoV) .$^{23,48}$ and Laem-Singh virus (LSNV). ${ }^{49}$

To conclude, the massive development of spheroid cells in the lymphoid organ of $P$. merguiensis from the broodstock population seems most likely to be due to defence mechanism to viral (PmeDV) infection. As a result, the health status of these two populations of banana prawn was remarkably different causing differential gene expression between populations, with some genes being induced in the Broodstock population. The up-regulation of these genes implicated their involvement in the immune responses. All in all, the current investigation has provided some valuable evidence on the up regulated genes in the lymphoid organ that may play crucial roles in viral defence responses in penaeid prawns. This could be used for further research on the host-viral interaction leading to a new immuneintervention approach that may help to circumvent the catastrophe of viral diseases in penaeid prawn industry.

\section{Acknowledgments}

The authors would like to thank Dr. Kathy La Fauce for reading the manuscript and offering valuable suggestions on the bench work. We also acknowledge northern Queensland prawn farmers for their excellent cooperation in supplying Penaeus merguiensis Broodstock for this research. This work partly supported by Graduate Research Scheme (GRS) Grant 2010 Faculty of Medicine, Health and Biomolecular Sciences, James Cook University. Rusaini was a recipient of Australian Development Scholarship (ADS) Program from Australian Agency for International Development (AusAID).

\section{Conflicts of interest}

None. 


\section{References}

1. Flegel TW, Lightner DV, Lo CF, et al. Shrimp diseases control: past, present and future. In: Bondad-Reantaso MG, Mohan CV, Crumlish M, Subasinghe RP (Eds), Diseases in Asian Aquaculture. Vol. VI. Fish Health Section, Asian Fisheries Society, Manila. 2008.

2. Walker PJ, Mohan CV. Viral disease emergence in shrimp aquaculture: Origins, impact and the effectiveness of health management strategies. Rev Aquac. 2009;1(2):125-154.

3. Chong YC, Loh H. Hepatopancreas chlamidial and parvoviral infections of farmed marine prawns in Singapore. Sing Vet. 1984;J 9:51-56.

4. Lightner DV, Redman RM. A parvo-like virus disease of penaeid shrimp. J Invertebr Pathol. 1985;5:47-53.

5. Roubal FR, Paynter JL, Lester RJG. Electron microscopic observation of hepatopancreatic parvo-like virus (HPV) in the penaeid prawn, Penaeus merguiensis de Man, from Australia. J Fish Dis. 1989;12:199-203.

6. Tang KFJ, Pantoja CR, Lightner DV. Nucleotide sequence of a Madagascar hepatopancreatic parvovirus (HPV) and comparison of genetic variation among geographic isolates. Dis Aquat Organ 2008;80(2):105-112.

7. La Fauce KA, Elliman J, Owens L. Molecular characterisation of hepatopancreatic parvovirus (PmergDNV) from Australian Penaeus merguiensis. Virology. 2007;362(2):397-403.

8. La Fauce KA, Layton R, Owens L. TaqMan real-time PCR for detection of hepatopancreatic parvovirus from Australia. J Virol Methods. 2007;140(1-2):10-16.

9. Owens L, Beer SD, Smith JLymphoidal parvovirus-like particles in Australian penaeid prawns. Dis Aquat Org. 1991;11:129-134.

10. Wang YT, Liu W, Seah JN, et al. White spot syndrome virus (WSSV) infects specific hemocytes of the shrimp Penaeus merguiensis. Dis Aquat Organ. 2002;52(3):249-259.

11. Owens L, McElnea C, Snape N, et al. Prevalence and effect of spawner-isolated mortality virus on the hatchery phases of Penaeus monodon and $P$. merguiensis in Australia. Dis Aquat Organ. 2003;53(2):101-106.

12. Spann KM, Donaldson RA, Cowley JA, et al. Differences in the susceptibility of some penaeid prawn species to gill-associated virus (GAV) infection. Dis Aquat Organ. 200042(3):221-225.

13. Anggraeni MS, Owens L. The haemocytic origin of lymphoid organ spheroid cells in the penaeid prawn Penaeus monodon. Dis Aquat Organ. 200040(2):85-92.

14. Anggraeni MS, Owens L. The haemocytic origin of lymphoid organ spheroid cells in the penaeid prawn Penaeus monodon. Dis Aquat Organ. 2000;40(2):85-92.

15. Mai WJ, Hu CQ. Molecular cloning, characterization, expression and antibacterial analysis of a lysozyme homologue from Fenneropenaeus merguiensis. Mol Biol Rep. 2009;36(6):1587-1595.

16. Phongdara A, Wanna W, Chotigeat W. Molecular cloning and expression of caspase from white shrimp Penaeus merguiensis. Aquaculture. 2006;252:114-120.

17. Rittidach W, Paijit N, Utarabhand P. Purification and characterization of a lectin from the banana shrimp Fenneropenaeus merguiensis hemolymph Biochim Biophys Acta. 2007;1770(1):106-114.

18. Loongyai W, Avarre JC, Cerutti M, et al. Isolation and functional characterization of a new shrimp ovarian peritrophin with antimicrobial activity from Fenneropenaeus merguiensis. Mar Biotechnol (NY). 2007;9(5):624-637.

19. Loongyai W, Phongdara A, Chotigeat W. Cloning and expression of a TCTP homolog from the ovaries of banana prawn. Mar Biol. 2007b;150:455-462.

20. Wonglapsuwan M, Phongdara A, Chotigeat W. Dynamic changes in gene expression during vitellogenic stages of the white shrimp: Fenneropenaeus merguiensis de Man. Aquac Res. 2009;40:633643

21. Wonglapsuwan M, Miyazaki T, Loongyai W, et al. Characterization and biological activity of the ribosomal protein L10a of the white shrimp: Fenneropenaeus merguiensis De Man during vitellogenesis. Mar Biotechnol. 2010;12(2):230-240.

22. Bell TA, Lightner DV. A Handbook of Normal Penaeid Shrimp Histology. The World Aquaculture Society, Baton Rauge, Louisiana. 1988.

23. Cowley JA, McCulloch RJ, Rajendran KV, et al. RT-nested PCR detection of Mourilyan virus in Australian Penaeus monodon and its tissue distribution in healthy and moribund prawns. Dis Aquat Organ. 2005;66(2):91-104.

24. Cotmore SF, Agbandje-McKenna M, Chiorini JA, et al. The family Parvoviridae. Arch Virol. 2014;159(5):1239-1247.

25. Ji W, Wright MB, Cai L, et al. Efficacy of SSH PCR in isolating differentially expressed genes. BMC Genomics. 2002;3:12.

26. Wang Z, Brown DD. A gene expression screen. Proc Natl Acad Sci USA. 1991;88(24):11505-11509.

27. Rusaini, Ariel E, Burgess GW, et al. Investigation of an idiopathic lesion in redclaw crayfish Cherax quadricarinatus using suppression subtractive hybridization. J Virol Microbiol (2013):DOI:10.5171/2013.569032.

28. Tsai JM, Wang HC, Leu JH, et al. Genomic and proteomic analysis of thirty-nine structural proteins of shrimp white spot syndrome virus. $J$ Virol. 2004;78(20):11360-11370.

29. Elliott RM. Bunyaviruses: General Features. In: Mahy BWJ, van Regenmortel MHV (Eds.), Encyclopedia of Virology (Third Edition). Academic Press, Oxford. 2008;pp.390-399.

30. van Regenmortel MHV, Fauquet CM, Bishop DHL, et al. Virus Taxonomy: Classification and Nomenclatur of Viruses. Seventh Report of the International Committee on Taxonomy of Virus. Academic Press, San Diego. 2000.

31. Cowley JA, McCulloch RJ, Spann KM, et al. Preliminary molecular and biological chracterization of Mourilyan virus (MoV): A new bunya-related virus of penaeid prawns. In: Walker P, Lester R, BondadReantaso $M G$ (Eds.), Diseases in Asian Aquaculture V. Fish Health Section, Asian Fishery Society, Manila. 2005b;pp.113-124.

32. Hasson KW, Lightner DV, Mohney LL, et al. Role of lymphoid organ spheroids in chronic Taura syndrome virus (TSV) infections in Penaeus vannamei. Dis Aquat Org. 1999;38:93-105.

33. Hasson KW, Lightner DV, Mohney LL, et al. Taura syndrome virus (TSV) lesion development and the disease cycle in the Pacific white shrimp Penaeus vannamei. Dis Aquat Org. 1999a;36:81-93.

34. Tang KFJ, Lightner DV. Duplex real-time PCR for detection and quantification of monodon baculovirus (MBV) and hepatopancreatic parvovirus (HPV) in Penaeus monodon. Dis Aquat Organ. 2011;93(3):191-198.

35. Owens L, Liessmann L, La Fauce K, et al. Intranuclear bacilliform virus and hepatopancreatic parvovirus (PmergDNV) in the mud crab Scylla serrata (Forskal) of Australia. Aquaculture. 2010;310:47-51.

36. Bonami JR, Lightner DV, Redman RM, et al. Partial characterisation of a togavirus (LOVV) associated with histopathological changes of the lymphoid organ of penaeid shrimps. Dis Aquat Org. 1992;14:145-152.

37. Nadala ECB, Lu Y, Loh PC, et al. Infection of Penaeus stylirostris (Boone) with a rhabdovirus isolated from Penaeus spp. Gyobyo Kenkyu. 1992;27:143-147. 
38. Spann KM, Vickers JE, Lester RJG Lymphoid organ virus of Penaeus monodon from Australia. Dis Aquat Org. 1995;23:127-134.

39. Spann KM, Cowley JA, Walker PJ, et al. A yellow-head-like virus from Penaeus monodon cultured in Australia. Dis Aquat Org. 1997;31:169-179.

40. Fraser CA, Owens L x Spawner-isolated mortality virus from Australian Penaeus monodon. Dis Aquat Org. 1997; 27:141-148.

41. Boonyaratpalin S, Supamattaya K, Kasornchandra J, et al.Non-occluded baculo-like virus, the causative agent of yellow head disease in the black tiger shrimp (Penaeus monodon). Gyobyo Kenkyu. 1993;28(3):103-109.

42. Chantanachookin C, Boonyaratpalin S, Kasornchandra J, Direkbusarakom S, et al. x Histology and ultrastructure reveal a new granulosis-like virus in Penaeus monodon affected by yellow-head disease. Dis Aquat Org. 1993;17:145-157.

43. Hasson KW, Lightner DV, Poulos BT, et al. Taura syndrome in Penaeus vannamei: Demonstration of a viral etiology. Dis Aquat Org. $1995 ; 23: 115-126$

44. Rodriguez J, Bayot B, Amano Y, et al. White spot syndrome virus infection in cultured Penaeus vannamei (Boone) in Ecuador with emphasis on histopathology and ultrastructure. J Fish Dis. 2003; 26(8):439-450.

45. Rodriguez $\mathrm{J}$, Ruiz $\mathrm{J}$, Maldonado $\mathrm{M}$, et al. Immunodetection of hemocytes, peneidins and $\alpha 2$-macroglobulin in the lymphoid organ of white spot syndrome virus infected shrimp. Microbiol Immunol. 2012;56(8):562-571.

46. Wu JL, Muroga K Apoptosis does not play an important role in the resistance of 'immune' Penaeus japonicus against white spot syndrome virus. J Fish Dis. 2004;27(1):15-21.

47. Tang KF, Pantoja CR, Poulos BT, x In situ hybridization demonstrates that Litopenaeus vannamei, L. stylirostris and Penaeus monodon are susceptible to experimental infection with infectious myonecrosis virus (IMNV). Dis Aquat Organ. 2004;63(2-3):261-265.

48. Rajendran KV, Cowley JA, McCulloch RJ, et al. A TaqMan real-time RT-PCR for quantifying Mourilyan virus infection levels in penaeid shrimp tissues. J Virol Methods. 2006;137(2):265-271.

49. Sritunyalucksana K, Apisawetakan S, Boon-nat A, et al. A new RNA virus found in black tiger shrimp Penaeus monodon from Thailand. Virus Res. 2006;118(1-2):31-38.

50. Amiard JC, Amiard-Triquet C, Barka S, et al. Metallothioneins in aquatic invertebrates: Their role in metal detoxification and their use as biomarkers. Aquat Toxicol. 2006;76(2):160-202 .

51. Antony SP, Philip R, Joseph V, Singh ISB. Anti-lipopolysaccharide factor and crustin-III, the anti-white spot virus peptides in Penaeus monodon: Control of viral infection by up-regulation. Aquaculture. 2011;319(1-2):11-17

52. Aoki H, Ahsan MN, Watabe S. Molecular cloning and characterization of cathepsin B from the hepatopancreas of northern shrimp Pandalus borealis. Comp Biochem Physiol B Biochem Mol Biol. 2003;134(4):681694.

53. Boulben S, Monnier A, Le Breton M, et al. Sea urchin elongation factor 1d (EF1d) and evidence for cell cycle-directed localization changes of a sub-fraction of the protein at M phase. Cell Mol Life Sci. 2003;60(10):2178-2188 .

54. Brenner BG, Wainberg Z. Heat shock proteins: Novel therapeutic tools for HIV-infection? Expert Opin Biol Ther. 2001;1(1):67-77.

55. Capaldi RA, Malatesta F, Darley-Usmar VM. Structure of cytochrome c oxidase. Biochim Biophys Acta. 1983;726(2):135-148.

56. Chen AJ, Wang S, Zhao XF, et al. Enzyme E2 from Chinese white shrimp inhibits replication of white spot syndrome virus and ubiquitinates Its RING domain proteins. J Virol. 2011;85(16):8069-8079

57. Chen FY, Liu HP, Bo J, et al. Identification of genes differentially expressed in hemocytes of Scylla paramamosain in response to lipopolysaccharide. Fish Shellfish Immunol. 2010;28(1):167-177.

58. Chen IT, Aoki T, Huang YT, et al. White spot syndrome virus induces metabolic changes resembling the Warburg effect in shrimp hemocytes in the early stage of Infection. J Virol. 2011;85(24):12919-12928.

59. Chongsatja PO, Bourchookarn A, Lo CF, et al. Proteomic analysis of differentially expressed proteins in Penaeus vannamei hemocytes upon Taura syndrome virus infection. Proteomics. 2007;7(19):3592-3601 .

60. Cimino EJ, Owens L, Bromage E, et al. A newly developed ELISA showing the effect of environmental stress on levels of hsp86 in Cherax quadricarinatus and Penaeus monodon. Comp Biochem Physiol A Integr Physiol. 2002;132(3):591-598 .

61. Cloonan SM, Choi AM. Mitochondria: commanders of innate immunity and disease? Curr Opin Immunol. 2012;24(1):32-40

62. Dalbey RE, Lively MO, Bron S, et al. The chemistry and enzymology of the type I signal peptidases. Protein Sci. 1997;6(6):1129-1138.

63. de la Vega E, Hall MR, Degnan BM, et al. Short-term hyperthermic treatment of Penaeus monodon increases expression of heat shock protein 70 (HSP70) and reduces replication of gill associated virus (GAV). Aquaculture. 2006;253(1-4):82-90 .

64. de la Vega E, O'Leary NA, Shockey JE, et al. Anti-lipopolysaccharide factor in Litopenaeus vannamei (LvALF): A broad spectrum antimicrobial peptide essential for shrimp immunity against bacterial and fungal infection. Mol Immunol. 2008;45(7):1916-1925.

65. Hastings KT, Cresswell P. Disulfide reduction in the endocytic pathway: immunological functions of gamma-interferon-inducible lysosoma thiol reductase. Antioxid Redox Signal. 2011;15(3):657-668 .

66. He N, Liu H, Xu X. Identification of genes involved in the response of haemocytes of Penaeus japonicus by suppression subtractive hybridization (SSH) following microbial challenge. Fish Shellfish Immunol. 2004;17(2):121-128 .

67. He N, Qin Q, Xu X. Differential profile of genes expressed in hemocytes of White Spot Syndrome Virus-resistant shrimp (Penaeus japonicus) by combining suppression subtractive hybridization and differential hybridization. Antiviral Res. 2005;66(1):39-45 .

68. Hild G, Bugyi B, Nyitrai M. Conformational dynamics of actin: effectors and implications for biological function. Cytoskeleton (Hoboken). 2010;67(10):609-629.

69. Ilback NG1, Glynn AW, Wikberg L, et al. Metallothionein is induced and trace element balance changed in target organs of a common viral infection. Toxicology. 2004;199(2-3):241-250 .

70. Jolesch A, Elmer $\mathrm{K}$, Bendz $\mathrm{H}$, et al. Hsp70, a messenger from hyperthermia for the immune system. Eur J Cell Biol. 2012;91(1):48-52

71. Kawaguchi Y, Bruni R, Roizman B. Interaction of herpes simplex virus 1 alpha regulatory protein ICP0 with elongation factor 1delta: ICP0 affects translational machinery. J Virol. 1997;71(2):1019-1024 .

72. Kerscher S, Drose S, Zickermann V, et al. The three families of respiratory NADH dehydrogenases. Results Probl Cell Differ. 2008;45:185-222.

73. Kongton K, Phongdara A, Tonganunt-Srithaworn M, et al. Molecular cloning and expression analysis of the interferon- $\gamma$-inducible lysosomal thiol reductase gene from the shrimp Penaeus monodon. Mol Biol Rep. 2011;38(5):3463-3470

74. Leu JH, Chang CC, Wu JL, et al. Comparative analysis of differentially expressed genes in normal and white spot syndrome virus infectedPenaeus monodon. BMC Genomics. 2007;8:120. 
75. Liu H, Jiravanichpaisal P, Soderhall I, et al. Antilipopolysaccharide factor Interferes with white spot syndrome virus replication in vitro and in vivo in the cray fish pacifastacus leniusculus. J Virol. 2006;80(21):10365-10371.

76. Liu HP, Chen RY, Zhang QX, et al. Differential gene expression profile from haematopoietic tissue stem cells of red claw crayfish, Cherax quadricarinatus, in response to WSSV infection. Dev Comp Immunol. 2011;35(7):716-724.

77. Luana W, Li F, Wang B, et al. Molecular characteristics and expression analysis of calreticulin in Chinese shrimp Fenneropenaeus chinensis. Comp Biochem Physiol B Biochem Mol Biol. 2007;147(3):482-491.

78. Miluzio A, Beugnet A, Volta V, et al. Eukaryotic initiation factor 6 mediates a continuum between $60 \mathrm{~S}$ ribosome biogenesis and translation. EMBO Rep. 2009;10(5):459-465

79. Mohankumar K, Ramasamy P. Activities of membrane bound phosphatases, transaminases and mitochondrial enzymes in white spot syndrome virus infected tissues of Fenneropenaeus indicus. Virus Res. 2006;118(1-2):130-135 .

80. Mort JS, Buttle DJ. Cathepsin B. Int J Biochem Cell Biol. 1997;29:715720 .

81. Nayak S, Singh SK, Ramaiah N, et al. Identification of upregulated immune-related genes in Vibrio harveyichallenged Penaeus monodon postlarvae. Fish Shellfish Immunol. 2010;29(3):544-549

82. Paetzel M, Karla A, Strynadka NCJ, et al. Signal Peptidases. Chem Rev. 2002;102(12):4549-4580

83. Passmore LA, Schmeing TM, Maag D, et al. The eukaryotic translation initiation factors eIF1 and eIF1A induce an open conformation of the 40S ribosome. Mol Cell. 2007;26(1):41-50.

84. Picard M, Taivassalo T, Gouspillou G, et al. Mitochondria: isolation, structure and function. J Physiol. 2011;589(18):4413-4421.

85. Pickart CM, Eddins MJ. Ubiquitin: Structures, functions, mechanisms Biochim Biophys Acta. 2004;1695(1-3):55-72.

86. Pongsomboon S, Tang S, Boonda S, et al. A cDNA microarray approach for analyzing transcriptional changes in Penaeus monodon after infection by pathogens. Fish Shellfish Immunol. 2011;30(1):439-446.

87. Pongsomboon S, Wongpanya R, Tang S, et al. Abundantly expressed transcripts in the lymphoid organ of the black tiger shrimp, Penaeus monodon, and their implication in immune function. Fish Shellfish Immunol. 2008;25(5):485-493 .

88. rapavorarat A, Pongsomboon S, Tassanakajon A. Identification of genes expressed in response to yellow head virus infection in the black tiger shrimp, Penaeus monodon, by suppression subtractive hybridization. Dev Comp Immunol. 2010;34(6):611-617.

89. iu Y, Michalak M. Transcriptional control of the calreticulin gene in health and disease. Int J Biochem Cell Biol. 2009;41(3):531-538 .

90. Ren Q, Zhou J, Sun SS, et al. Molecular cloning and expression pattern analysis of two novel disulfide isomerases in shrimp. Comp Biochem Physiol C Toxicol Pharmacol. 2011;153(3):301-309.

91. Riis B, Rattan SI, Clark BF, et al. Eukaryotic protein elongation factors. Trends Biochem Sci. 1990;15(11):420-424.

92. Roesijadi G. Metallothioneins in metal regulation and toxicity in aquatic animals. Aquat Toxicol. 1992;22:81-113.
93. Rungrassamee W, Leelatanawit R, Jiravanichpaisal P, et al. Expression and distribution of three heat shock protein genes under heat shock stress and under exposure to Vibrio harveyi in Penaeus monodon. Dev Comp Immunol. 2010;34(10):1082-1089.

94. arkar M, Das S, Bandyopadhaya A, et al. Upregulation of human mitochondrial NADH dehydrogenase subunit 5 in intestinal epithelial cells is modulated by Vibrio cholerae pathogenesis. FEBS Lett. 2005;579(16):3449-3460.

95. omboonwiwat K, Bachere E, Rimphanitchayakit V, et al. Localization of anti-lipopolysaccharide factor (ALFPm3) in tissues of the black tiger shrimp, Penaeus monodon, and characterization of its binding properties. Dev Comp Immunol. 2008;32(10):1170-1176

96. Stephens A, Rojo L, Araujo-Bernal S, et al. Cathepsin B from the white shrimp Litopenaeus vannamei: cDNA sequence analysis, tissuesspecific expression and biological activity. Comp Biochem Physiol B Biochem Mol Biol. 2012;161(1):32-40.

97. Turk V, Stoka V, Vasiljeva O, et al. Cysteine cathepsins: From structure, function and regulation to new frontiers. Biochim Biophys Acta. 2012;1824(1):68-88.

98. Vargas-Albores F, Martinez-Martinez A, Aguilar-Campos J, et al. The expression of protein disulfide isomerase from Litopenaeus vannamei hemocytes is regulated by bacterial inoculation. Comp Biochem Physiol Part D Genomics Proteomics. 2009;4(3):141-146.

99. Wang B, LiF, Dong B, et al. Discovery of the genes in response to white spot syndrome virus (WSSV) infection in Fenneropenaeus chinensis through cDNA microarray. Mar Biotechnol (NY).2006;8(5):491-500.

100. Wang HC, Wang HC, Leu JH, et al. Protein expression profiling of the shrimp cellular response to white spot syndrome virus infection. Dev Comp Immunol. 2007;31(7):672-686.

101. Wang S, Liu N, Chen AJ, et al. TRBP homolog interacts with eukaryotic initiation factor 6 (eIF6) in Fenneropenaeus chinensis. J Immunol. 2009;182(9):5250-5258.

102. Wang X, Liu B, Wang G, et al. Molecular cloning and functional analysis of cathepsin B in nutrient metabolism during larval development in Meretrix meretrix. Aquaculture. 2008;282(1-4):41-46.

103. Wang Z, Chua HK, Gusti AA, et al. RING-H2 protein WSSV249 from white spot syndrome virus sequesters a shrimp ubiquitin-conjugating enzyme, PvUbc, for viral pathogenesis. J Virol. 2005;79(14):8764-8772.

104. Wilkinson B, Gilbert HF. Protein disulfide isomerase. Biochim Biophys Acta. 2004;1699(1-2):35-44.

105. Wu H, Shi Y, Lin Y, et al. Eukaryotic translation elongation factor 1 delta inhibits the ubiquitin ligase activity of SIAH-1. Mol Cell Biochem. 2011;357(1-2):209-215.

106. Wu W, Zong R, Xu J, et al. Antiviral phagocytosis is regulated by a novel Rab-dependent complex in shrimp Penaeus japonicus. J Proteome Res. 2007;7(1):424-431.

107. Zhang J, Li F, Jiang H, et al. Proteomic analysis of differentially expressed proteins in lymphoid organ of Fenneropenaeus chinensis response to Vibrio anguillarum stimulation. Fish Shellfish Immunol. 2010;29(2):186-194.

108. Pourang N, Dennis JH, Ghourchian H. Tissue distribution and redistribution of trace elements in shrimp species with emphasis on the roles of metallothionein. Ecotoxicology. 2004;13(6):519-533. 